\title{
CARCASS PARAMETERS OF SUDANI, MUSCOVY DUCK STRAINS AND THEIR CROSS
}

\author{
A. Makram, A. Galal and A.H. El-Attar \\ Poultry Production Department, Faculty of Agriculture, Ain Shams University, Cairo, Egypt \\ Corresponding author: Amer Makram.E-mail Am150@Fayoum.edu.eg
}

\section{SUMMARY}

Cross breeding was used as a means of improving carcass quality. White Pekin and White Muscovy ducks differ in growth rate and carcass composition. The Muscovy males (M) were allowed to naturally mate with Sudani (S) females. When the ducklings attained marketing age, 16 birds (8 males +8 females) from each strain, in addition to their cross were randomly taken and slaughtered for carcass evaluation. The results revealed that there was no significant difference obtained for relative dressed weight due to strain. With respect to sex effect, the males were significantly higher than the females in dressed percentage. With respect to relative giblets weight, the MS cross had significantly higher giblets compared to Muscovy duck, while, Sudani duck was intermediate. The relative weight of edible meat parts was not significantly affected either by strain, or interaction between sex and strain, however, males had significantly higher relative edible meat parts weight compared to females one. The MS cross had significantly heavier thigh muscle percentage compared to Sudani one, followed by the Muscovy duck, males were significantly higher compared to females. Finally, the MS cross recorded negative heterosis for edible meat parts, major, minor, breast muscles skin, neck and wings. The MS cross recorded positive heterosis for giblets, thigh, drumstick, gizzard fat and abdominal fat.

\section{Keywords: Carcass parameters, Sudani, Muscovy duck, Cross, Heterosis}

\section{INTRODUCTION}

Water fowl have been used by humans for meat, fattened livers, eggs and feather for over 5000 years (Stanislaw Wezyk, 1999). The Muscovy duck (Cairina moschata) is distinctly different genetically from common ducks. This breed is believed to have originated in South America, although ancient records of this or a similar breed have been found in Egypt. The Sudani can be considered a line from Muscovy found in Egypt (Makram, 2016). Muscovy ducks, like chickens and turkeys, can be used for meat production. The carcass dressing percentage of Muscovy ducks is about $74 \%$ (Wawro et al., 2004). Cross breeding was used as means of improving carcass quality. White Pekin and White Muscovy ducks differ in growth rate and carcass composition. The Muscovy breed possesses more lean tissues and less subcutaneous fat than the Pekin (Farhat, 1999). Cross breeding of these two duck breeds has been used as a tool to modify carcass composition. Crossing Pekin with Muscovy produced an infertile mule duck (Abdel- Samie and Farrell, 1986) with improved carcass yield and quality (Vernam, 1998). The carcass of this hybrid had $17.0 \%$ skin plus fat and $14.6 \%$ muscle compared to pure Pekin which had a $26.6 \%$ skin plus fat and 12.9\% muscle (Abdel- Samie and Farrell, 1986). Sudani females, characterized by natural breeding, which makes it easy to apply and also characterized by high immunity and small size and this reduces the cost of rearing. This experiment was designed to evaluate carcass parameters among Muscovy, Sudani and their cross

\section{MATERIALS AND METHODS}

This experiment was carried out at a private farm in Fayoum Governorate. A total number 275 (150 Sudani and 125 Muscovy) one day old un-sexed ducks were used. They were reared under similar environmental, managerial and hygienic conditions from one day old to the end of the experiment. The feed and water were supplied ad libtium. They were fed diet contained $22 \%$ protein $(\mathrm{P})$ and $2900 \mathrm{Kcal}$ for Sudani, Muscovy and the cross (0-4 wk), $20 \% \mathrm{P}$ and 2900 Kcal for Sudani Muscovy and their cross (4 wks - marketing age). At 32 wk of age, the 7 Muscovy males (M) were allowed to naturally mating with 28 Sudani (S) female (each male was mated with 4 females). The total number offspring produce from this mating were 115 ducklings. .

\section{Measurements and observations: \\ Carcass measurements:}

When the ducklings attained marketing age, 16 birds ( 8 males +8 females) from each strain, in addition their cross were randomly taken and slaughtered for carcass evaluation. They were slaughtered after weighing. Then they were reweighed after bleeding to calculate blood weight by difference. Feathers were manually plucked up after scalding in hot water, and then the birds were reweighed to calculate feathers weight by difference. Head, shank and foot were weighed after removing. The birds were eviscerated by removing the viscera. The giblets (gizzard, liver and heart) were dissected from the viscera and the gizzard was cut, open and cleaned from its contents. The abdominal fat, gizzard fat and skin was removing and weighing. The wings 
and neck were removed and weighed. The carcass, thigh, drumstick and breast muscles (minor and major) were weighed. All parts were expressed as percentage of the live body weight.

\section{Heterosis:}

The crossbreed effect (Hybrid vigor) or hetrosis expressed as a percent was calculated as the superiority of the crossbred ducks over that of the pure bred ones. The heterosis was calculated as follows:

Heterosis $\%=\frac{\text { Mean cross bred (XC)-Mean pure bred (XP) }}{\text { Mean pure bred (XP) }}$ X100

\section{Statistical analysis:}

Data were subjected to a two-way analysis of variance with strain and sex with interaction using General Linear Model (GLM) procedure of SAS (2001) as following model (II);

$$
\mathbf{Y}_{\mathrm{ij}}=\boldsymbol{\mu}+\mathbf{S}_{\mathrm{i}}+\mathbf{T}_{\mathbf{j}}+[\mathbf{S x T}]_{\mathrm{ij}}+\mathbf{e}_{\mathrm{ijk}}
$$

Where; $Y_{i j}=$ Trait measured, $\mu=$ Overall mean, $S_{i}=$ Strain effect ( $i=1,2,3,4$ and 5$)$,

$\mathrm{T}_{\mathrm{j}}=\operatorname{sex}$ effect $(\mathrm{j}=1$ and 2$)[\mathrm{SxT}]_{\mathrm{ij}}=$ Interaction between strain and sex, $\mathrm{e}_{\mathrm{ijk}}=$ Experimental error.

When significant differences among means were found, means were separated using Duncan's multiple range tests.

\section{Carcass Parameters:}

Non edible meat parts:

Effect of sex, strain and their interaction on relative non edible meat parts weight of parents and MS cross are summarized in Table (1). Muscovy duck strain had heaviest body weight compared to Sudani and MS cross. With respect to sex effect, the males had significant heavier live body weight than the females, live body weight was significantly affected by interaction between sex and strain. Kim et al., (2010) found that males had significantly higher live body weight than females of cross between the native korena duck X Muscovy duck and reciprocal cross. For blood percentage, it could be noticed that the MS cross was significantly $(p<0.05)$ lowest compared to their Parents. Muscovy duck recorded significantly higher relative feather weight compared to Sudani duck strain, however MS cross was intermediate. Conversely, the Muscovy duck strain had the lowest relative head weight compared to Sudani or MS cross. For relative leg and nonedible meat parts, there was no significant difference among strains, sex and their interaction. Kim et al. (2010) found that no significant difference between males and females for leg between the cross native korena duck X Muscovy duck and reciprocal cross.

\section{RESULTS AND DISCUSSION}

Table 1 Effect (mean \pm E) of sex, strain and their interaction on relative non-edible meat parts of parental duck strains and MS cross at marketing age

\begin{tabular}{|c|c|c|c|c|c|c|c|c|}
\hline \multirow[b]{2}{*}{ Traits } & \multirow[b]{2}{*}{$\operatorname{Sex}(\mathbf{S x})$} & \multicolumn{2}{|c|}{ Breed Group (BG) } & \multirow[b]{2}{*}{ MS* Cross } & \multirow[b]{2}{*}{ Overall } & \multicolumn{3}{|c|}{ Level of significant } \\
\hline & & $\begin{array}{c}\text { Muscovy } \\
\text { (M) }\end{array}$ & Sudani (S) & & & BG & $\mathbf{S x}$ & $\mathbf{S} * \mathbf{S x}$ \\
\hline \multirow{4}{*}{$\begin{array}{l}\text { Live body } \\
\text { weight }\end{array}$} & Males & $3800.7 \pm 90.2$ & $2993.1 \pm 63.8$ & $2924.4 \pm 167.9$ & $299^{\mathrm{a}}$ & & & \\
\hline & Females & $2438.9 \pm 117.9$ & $1678.1 \pm 100.7$ & $2032.5 \pm 141.3$ & $2065^{\mathrm{b}}$ & & & \\
\hline & Overall & $3034.7^{\mathrm{a}}$ & $2335.6^{b}$ & $2157.8^{b}$ & & 0.0001 & 0.0001 & 0.0001 \\
\hline & Males & $3.2 \pm 0.4$ & $4.2 \pm 0.5$ & $3.6 \pm 0.5$ & 3.9 & & & \\
\hline \multirow[t]{2}{*}{ Blood, \% } & Females & $4.1 \pm 0.2$ & $3.4 \pm 0.3$ & $2.6 \pm 0.3$ & 3.4 & & & \\
\hline & Overall & $3.8^{\mathrm{a}}$ & $3.9^{\mathrm{a}}$ & $3.1^{\mathrm{b}}$ & & 0.05 & $\mathrm{NS}$ & NS \\
\hline \multirow[t]{3}{*}{ Feather, $\%$} & Males & $9.1 \pm 0.8$ & $7.2 \pm 0.5$ & $8.3 \pm 0.3$ & 8.1 & & & \\
\hline & Females & $8.6 \pm 0.7$ & $7.4 \pm 0.4$ & $7.6 \pm 0.7$ & 7.9 & & & \\
\hline & Overall & $8.3^{\mathrm{a}}$ & $7.3^{\mathrm{b}}$ & $7.9^{\mathrm{ab}}$ & & 0.05 & NS & NS \\
\hline \multirow[t]{3}{*}{ Head, \% } & Males & $3.5 \pm 0.4$ & $3.7 \pm 0.12$ & 3. $8 \pm 0.12$ & 3.7 & & & \\
\hline & Females & $3.4 \pm 0.3$ & $4.1 \pm 0.01$ & $4.0 \pm 0.1$ & 3.8 & & & \\
\hline & Overall & $3.4^{\mathrm{b}}$ & $3.9^{\mathrm{a}}$ & $3.9^{\mathrm{a}}$ & & 0.05 & NS & NS \\
\hline \multirow[t]{3}{*}{ Leg, $\%$} & Males & $3.2 \pm 0.7$ & $3.0 \pm 0.1$ & $2.9 \pm 0.1$ & 3.0 & & & \\
\hline & Females & $2.7 \pm 0.3$ & $2.8 \pm 0.1$ & $2.5 \pm 0.1$ & 3.6 & & & \\
\hline & Overall & 2.9 & 2.9 & 2.7 & & NS & NS & NS \\
\hline \multirow{3}{*}{$\begin{array}{l}\text { Non edible } \\
\text { meat parts \% }\end{array}$} & Males & $18.4 \pm 0.7$ & $18.2 \pm 0.4$ & $18.3 \pm 0.7$ & 18.3 & & & \\
\hline & Females & $18.1 \pm 0.5$ & $17.7 \pm 0.5$ & $16.7 \pm 0.9$ & 17.5 & & & \\
\hline & Overall & 18.2 & 18.0 & 14.4 & & NS & NS & NS \\
\hline
\end{tabular}

\section{Edible meat parts:}

Data presented in table (2) illustrate information about effect of sex, breed group and their interaction on relative edible meat parts weight of parents and MS cross (at marketing age). No significant difference obtained for relative dressed weight due to breed group. With respect to sex effect, the males were significantly higher in dressed percentage than females, the interaction was not significant. Relative gizzard weight was significantly affected by strain, whereas Sudani duck had significantly higher gizzard percentage compared to Muscovy or MS cross. The MS cross had significantly higher relative liver weight compared to their parents. With respect to relative giblets weight, the MS cross was significantly higher compared to Muscovy ducks, 
while, Sudani ducks were intermediate. Finally, occupied the last point on the relative edible meat parts weight was not significantly affected either by breed group, or interaction between sex and strain, however, males had significantly higher relative edible meat parts weight compared to the female ones. Our results agree with the finding of Marie-
Etancelin et al., (2008) who stated that the slaughter weight and carcass parameters were higher in male than in female broiler ducks slaughtered at 8 weeks of age in order to have better slaughter and carcass parameters.

Table 2. Effect (means \pm SE) of sex, strain and their interaction on relative edible meat parts of parental duck strains and MS cross at marketing age

\begin{tabular}{|c|c|c|c|c|c|c|c|c|}
\hline \multirow[b]{2}{*}{ Traits } & \multirow[b]{2}{*}{$\operatorname{Sex}(\operatorname{Sx})$} & \multicolumn{2}{|c|}{ Breed Group (BG) } & \multirow{2}{*}{$\begin{array}{l}\text { MS* } \\
\text { Cross }\end{array}$} & \multirow[b]{2}{*}{ Overall } & \multicolumn{3}{|c|}{ Level of significant } \\
\hline & & $\begin{array}{l}\text { Muscovy } \\
\text { (M) }\end{array}$ & $\begin{array}{l}\text { Sudani } \\
\text { (S) }\end{array}$ & & & BG & $\mathbf{S x}$ & $\mathbf{S} * \mathbf{S x}$ \\
\hline \multirow{3}{*}{$\begin{array}{l}\text { Dressed } \\
\text { carcass, \% }\end{array}$} & Males & $71.6 \pm 2.2$ & $69.9 \pm 0.7$ & $67.5 \pm 0.7$ & $69.6^{\mathrm{a}}$ & & & \\
\hline & Females & $68.5 \pm 0.9$ & $66.4 \pm 1.0$ & $67.6 \pm 0.5$ & $67.5^{b}$ & & & \\
\hline & Overall & 70.0 & 68.2 & 67.5 & & NS & 0.02 & NS \\
\hline \multirow[t]{3}{*}{ Gizzard, \% } & Males & $2.0 \pm 0.1$ & $2.9 \pm 0.2$ & 2. $7 \pm 0.1$ & 2.4 & & & \\
\hline & Females & $2.3 \pm 0.1$ & $2.82 \pm 0.1$ & $2.41 \pm 0.2$ & 2.5 & & & \\
\hline & Overall & $2.2^{\mathrm{b}}$ & $2.9^{\mathrm{a}}$ & $2.4^{\mathrm{b}}$ & & 0.0001 & NS & NS \\
\hline \multirow[t]{3}{*}{ Liver, \% } & Males & $2.0 \pm 0.1$ & $1.9 \pm 0.1$ & $2.3 \pm 0.2$ & 2.4 & & & \\
\hline & Females & $2.1 \pm 0.2$ & $1.9 \pm 0.1$ & $2.6 \pm 0.2$ & 2.2 & & & \\
\hline & Overall & $2.1^{\mathrm{b}}$ & $1.9^{\mathrm{b}}$ & $2.9^{\mathrm{a}}$ & & 0.0001 & NS & 0.03 \\
\hline \multirow[t]{3}{*}{ Heart, \% } & Males & $0.96 \pm 0.09$ & $0.83 \pm 0.04$ & $0.71 \pm 0.04$ & 0.83 & & & \\
\hline & Females & $0.72 \pm 0.04$ & $0.77 \pm 0.05$ & $0.87 \pm 0.08$ & 0.78 & & & \\
\hline & Overall & 0.83 & 0.80 & 0.79 & & NS & NS & 0.003 \\
\hline \multirow[t]{3}{*}{ Giblets, \% } & Males & $5.0 \pm 0.1$ & $5.6 \pm 0.2$ & $6.3 \pm 0.2$ & 5.7 & & & \\
\hline & Females & $5.129 \pm 0.2$ & $5.54 \pm 0.2$ & $5.85 \pm 0.3$ & 5.5 & & & \\
\hline & Overall & $5.1^{\mathrm{c}}$ & $5.6^{\mathrm{b}}$ & $6.1^{\mathrm{a}}$ & & 0.0001 & NS & NS \\
\hline \multirow{3}{*}{$\begin{array}{l}\text { Edible meat } \\
\text { parts, } \%\end{array}$} & Males & $76.6 \pm 2.2$ & $75.5 \pm 0.5$ & $73.9 \pm 0.6$ & $75.38^{a}$ & & & \\
\hline & Females & $73.7 \pm 0.8$ & $72.0 \pm 0.8$ & $72.2 \pm 0.9$ & $732.6^{b}$ & & & \\
\hline & Overall & 75.0 & 73.8 & 73.2 & & $\mathrm{NS}$ & 0.003 & NS \\
\hline
\end{tabular}

${ }^{\mathrm{a}, \mathrm{b} \text { and } \mathrm{c}}$ Means within the same row with different letters are significantly differed NS $=$ Non significant

$* \mathbf{M S}=$ the cross between Muscovy male with Sudani female

\section{Relative breast, thigh and drumstick weight:}

Relative breast, thigh and drumstick muscles weight of MS cross and their parents as affected by breed group, sex and their interaction are presented in Table (3). There was significant difference among breed group for relative major pectorals muscle weight, the MS cross had lowest relative major compared to their parents, the sex effect was not significant, but the interaction between sex and strain was significant. Such results attributed to the males of parental strains had higher relative major weight than female while, the females of MS cross exhibited a higher relative major weight than there males. Opposite trend was noticed for MS cross when compared to their parent of relative minor weight. With respect to relative breast muscles weight, the Sudani and Muscovy duck strains had significantly higher breast percentage compared to MS cross, the males had significantly heavier relative breast muscles weight compared to females, breast percentage was significantly affected by interaction between sex and strain. Meat quality depends on a number of factors. Of the biological ones, the greatest impact is produced by genotype, sex and age (Bokkers and Koene, 2003; Hellmeister et al., 2003; and Kwon et al., 2014). When, the age of the ducks exceeds 8 weeks in Peking duck the muscles no longer gain in weight, while, the gain of skin with subcutaneous fat increases (Gorski and Wzrost, 1990 and Gorski, 1997ab, Makram, 2015 and Makram et al., 2015). The tissue composition of carcasses changes with age, because particular components show different growth rates. The percentage of meat and skin fat increases, whereas the percentage of bones decreases, as birds grow older. These changes are more radical in ducks than in chickens (Bochno and Lewczuk, 1986). There was significant difference among strains for relative thigh muscle weight. Whereas, the MS cross had significantly heavier thigh muscle percentage compared to Sudani one, followed by the Muscovy duck. Males were significantly higher compared to females. Finally, effect for strain or sex affected relative drumstick weight however; the interaction between sex and strain was significant. Muscovy ducks, reared in many European countries, are usually characterized by lower fatness, higher meatiness and meat had better quality than Pekin ducks (Pikul et al., 1987; Ricard et al., 1988; Pingel, 1997; Baeza et al., 1998; Zeidler, 1998). According to Baeza et al. (1998), the quality and palatability of breast muscles of Muscovy ducks deteriorate with age. They become less juicy and more tough (less tender), which is connected with decreased collagen solubility accompanied by 
increased thickness of muscle fibers. Kim et al. (2010) reported that males had significantly higher breast muscles than females for the cross between the native korena duck x Muscovy duck and reciprocal cross.

Table 3 Relative. (means \pm SE) breast, thigh and drumstick muscles weight parental duck strains and MS cross.

\begin{tabular}{|c|c|c|c|c|c|c|c|c|}
\hline \multirow[b]{2}{*}{ Traits } & \multirow[b]{2}{*}{$\begin{array}{l}\text { Sex } \\
\text { (Sx) }\end{array}$} & \multicolumn{2}{|c|}{ Breed Group (BG) } & \multirow{2}{*}{$\begin{array}{l}\text { MS* } \\
\text { Cross }\end{array}$} & \multirow[b]{2}{*}{ Overall } & \multicolumn{3}{|c|}{ Level of significant } \\
\hline & & $\begin{array}{c}\text { Muscovy } \\
\text { (M) }\end{array}$ & $\begin{array}{l}\text { Sudani } \\
\text { (S) }\end{array}$ & & & BG & $\mathbf{S x}$ & $S t * S x$ \\
\hline \multirow[t]{3}{*}{ Major, \% } & Males & $15.4 \pm 0.9$ & $12.9 \pm 0.4$ & $7.3 \pm 0.4$ & 11.7 & & & \\
\hline & Females & $11.2 \pm 1.2$ & $10.9 \pm 0.8$ & $9.8 \pm 0.6$ & 10.7 & & & \\
\hline & Overall & $13.0^{\mathrm{a}}$ & $11.9^{\mathrm{a}}$ & $8.5^{\mathrm{b}}$ & & 0.0001 & NS & 0.0009 \\
\hline \multirow[t]{3}{*}{ Minor, \% } & Males & $2.0 \pm 0.1$ & $1.8 \pm 0.1$ & $1.4 \pm 0.1$ & 1.7 & & & \\
\hline & Females & $1.7 \pm 0.2$ & $1.6 \pm 0.1$ & $1.6 \pm 0.1$ & 1.7 & & & \\
\hline & Overall & $1.8^{\mathrm{a}}$ & $1.7^{\mathrm{a}}$ & $1.5^{\mathrm{b}}$ & & 0.002 & NS & NS \\
\hline \multirow[t]{3}{*}{ Breast, \% } & Males & $17.3 \pm 1.0$ & $14.7 \pm 0.5$ & $8.7 \pm 0.4$ & $13.4^{\mathrm{a}}$ & & & \\
\hline & Females & $12.9 \pm 1.4$ & $12.5 \pm 0.9$ & $10.7 \pm 0.8$ & $12.1^{\mathrm{b}}$ & & & \\
\hline & Overall & $14.8^{\mathrm{a}}$ & $13.6^{\mathrm{a}}$ & $9.7^{\mathrm{b}}$ & & 0.0001 & 0.05 & 0.004 \\
\hline \multirow[t]{3}{*}{ Thigh, \% } & Males & $4.1 \pm 0.2$ & $4.4 \pm 0.3$ & $5.6 \pm 0.4$ & $4.7^{\mathrm{a}}$ & & & \\
\hline & Females & $6.3 \pm 0.5$ & $4.6 \pm 0.3$ & $8.4 \pm 0.4$ & $6.4^{\mathrm{b}}$ & & & \\
\hline & Overall & $5.3^{\mathrm{b}}$ & $4.5^{\mathrm{c}}$ & $7.0^{\mathrm{a}}$ & & 0.0001 & 0.0001 & 0.002 \\
\hline \multirow{3}{*}{$\begin{array}{l}\text { Drumstick, } \\
\%\end{array}$} & Males & $6.9 \pm 0.4$ & $7.2 \pm 0.2$ & $8.8 \pm 0.3$ & 7.6 & & & \\
\hline & Females & $7.4 \pm 0.7$ & $8.1 \pm 0.4$ & $6.0 \pm 0.4$ & 7.2 & & & \\
\hline & Overall & 7.1 & 7.6 & 7.4 & & NS & NS & 0.003 \\
\hline
\end{tabular}

a, and $b$ Means within the same row with different letters are significantly differed

*MS $=$ the cross between Muscovy male with Sudani female

Percentage of abdominal fat, gizzard fat, skin, neck and wings MS Cross:

Data present in table (4) show the effect of breed group, sex and their interaction on relative gizzard fat, abdominal fat, skin, neck and wings weight of MS cross and their parents. It could be noticed that the MS cross had significantly higher relative gizzard fat weight compared to Sudani one. However, the Muscovy duck strain was intermediate, female recorded significantly higher relative gizzard fat compared to male duck. No significant differences were detected between sex and strain of relative abdominal fat weight. The females had significantly higher abdominal fat percentage compared to males. The Muscovy ducks were significantly higher relative skin weight compared to MS cross, however the Sudani ducks were intermediate. The Sudani ducks were significantly higher relative neck weight compared to MS cross, however Muscovy duck was intermediated. There was no significant difference between sex and duck breed group for skin or neck percentage. Pingel (1999) confirmed that the breast muscle was decreased and the skin was increased in Muscovy, Pekin and Mulard before marketing age, however the interaction was significant. Kim et al., (2010) found no significant difference ct between males and females for wings and neck for the cross between native korena ducks X Muscovy ducks and their reciprocal cross.

Table 4. Relative (means \pm SE) abdominal, gizzard fat, neck and wings weight parental duck strains and MS cross

\begin{tabular}{|c|c|c|c|c|c|c|c|c|}
\hline Traits & Sex & Strains & & & Overall & Prob & & \\
\hline & & Sudani & Muscovy & MS* Cross & & $\mathbf{S}$ & SX & $S * T$ \\
\hline \multirow[t]{3}{*}{ Gizzard fat $\%$} & Male & $0.044 \pm 0.030$ & $0.239 \pm 0.056$ & $0.260 \pm 0.091$ & $0.178^{b}$ & & & \\
\hline & Female & $0.345 \pm 0.124$ & $0.426 \pm 0.096$ & $0.624 \pm 0.11$ & $0.463^{\mathrm{a}}$ & & & \\
\hline & Overall & $0.194^{\mathrm{b}}$ & $0.344^{\mathrm{ab}}$ & $0.442^{\mathrm{a}}$ & & 0.03 & 0.0005 & N.S \\
\hline Abdominal fat & Male & $0.901 \pm 0.146$ & $0.867 \pm 0.139$ & $0.904 \pm 0.197$ & $0.891^{\mathrm{a}}$ & & & \\
\hline \multirow[t]{2}{*}{$\%$} & Female & $1.306 \pm 0.257$ & $1.372 \pm 0.209$ & $1.449 \pm 0.108$ & $1.373^{\mathrm{b}}$ & & & \\
\hline & Overall & 1.117 & 1.151 & 1.158 & & N.S & 0.004 & N.S \\
\hline \multirow[t]{3}{*}{ Skin \% } & Male & $7.6 \pm 0.38$ & $7.8 \pm 0.54$ & $6.6 \pm 0.51$ & 7.2 & & & \\
\hline & Female & $8.9 \pm 1.07$ & $9.2 \pm 0.66$ & $7.3 \pm 0.24$ & 8.3 & & & \\
\hline & Overall & $7.9^{\mathrm{ab}}$ & $8.6^{\mathrm{a}}$ & $6.9^{b}$ & & 0.04 & N.S & N.S \\
\hline \multirow[t]{3}{*}{ Neck \% } & Male & $4.3 \pm 0.26$ & $3.5 \pm 0.21$ & $3.7 \pm 0.08$ & 3.8 & & & \\
\hline & Female & $3.8 \pm 0.20$ & $3.8 \pm 0.35$ & $3.5 \pm 0.17$ & 3.7 & & & \\
\hline & Overall & $4.05^{\mathrm{a}}$ & $3.61^{\mathrm{ab}}$ & $3.55^{\mathrm{b}}$ & & 0.05 & N.S & N.S \\
\hline \multirow[t]{3}{*}{ Wings \% } & Male & $11.2 \pm 0.35$ & $10.2 \pm 0.50$ & $9.9 \pm 0.30$ & 10.5 & & & \\
\hline & Female & $9.2 \pm 0.309$ & $10.4 \pm 0.347$ & $10.3 \pm 0.43$ & 10.0 & & & \\
\hline & Overall & 10.21 & 10.30 & 10.14 & & N.S & N.S & 0.004 \\
\hline
\end{tabular}

$\mathrm{a}, \mathrm{b}$ and $\mathrm{c}$ Means within the same row with different letters are significantly differed NS $=$ Non significant $* \mathbf{M S}=$ the cross between Muscovy male with Sudani female 


\section{Hetrosis:}

\section{Cross effect:}

Effect of heterosis on carcass parameters of MS cross is summarized in Table (5). The present results show negative heterosis for dresses, gizzard and edible meat parts $(-2.30,-4.03$ and $2.02 \%$ respectively), however, there was positive heterosis for live body weight, liver heart and giblets (5.44, $47.30,0.244$ and $15.17 \%$ respectively). With respect to breast muscle, the MS cross recorded negative heterosis for major, minor and breast muscles; however, there was positive heterosis for thigh, drumstick, gizzard fat and abdominal fat. The MS cross recorded negative heterosis for skin, neck and wings. Makram et al. (2016) found negative hetrosis for liver and gizzard for the developed hybrids from Sudani duck strain.

\section{Sex effect:}

Effects of sex on heterosis of carcass parameters of MS cross are summarized in table (5). The present results show negative heterosis for live body weight. Negative heterosis was observed for dressed carcass in males. Opposite trend was noticed in females. Both males and females had negative heterosis for gizzard; however females recorded high negative heterosis compared to males. With respect to liver, both males and females had positive heterosis, however males had higher positive heterosis $(67.15 \%)$ compared to females $(25.87 \%)$. Males recorded negative heterosis $(-17.20)$ for heart, while, females recorded positive heterosis (20.89\%). Concerning giblets, the male's recorded high positive heterosis $(20.96 \%)$ compared to females $(9.54 \%)$. Finally, both males and females had negative heterosis for edible meat parts. The males and females recorded negative hetrosis for major, minor pectoral muscles and breast muscles, however, males recorded high negative heterosis $(-43.94 \%)$ for breast muscles compared to females $(-10.71 \%)$. The females recorded high positive heterosis $(61.70 \%)$ for thigh compared to males $(26.67 \%)$. However, females had negative heterosis for drumstick $(-18.38 \%)$, while, males had positive heterosis $(29.26 \%)$. Both males and females recorded positive heterosis for gizzard fat, abdominal fat and skin; however the males had higher positive heterosis for gizzard fat compared to females one, opposite trend was noticed for abdominal fat. Wawro et al. (2004).reported that evaluation of the heterosis effect in both sex groups shows that it was present first of all in such traits as the weight and percentage of breast muscles in a carcass $(9.2 \%$ and $18.4 \%$ respectively), and total meat content of a carcass $(10.1 \%$ and $18.6 \%$, respectively).

Table 5. Effect of heterosis (\%) and sex on carcass traits of MS cross

\begin{tabular}{lccc} 
& \multirow{2}{*}{ Trait } & \multicolumn{3}{c}{ MS* Cross } \\
\cline { 2 - 3 } & Male & Female & -2.30 \\
Dressed & -4.04 & 0.36 & -4.03 \\
Gizzard & -0.42 & -5.75 & 47.30 \\
Liver & 67.15 & 25.87 & 0.244 \\
Heart & -17.20 & 20.89 & 15.17 \\
Giblets & 20.96 & 9.54 & -2.02 \\
Edible meat parts & -2.65 & -0.89 & -30.89 \\
Major pectoral muscle & -46.67 & -7.25 & -15.43 \\
Minor pectoral muscle & -22.89 & -6.83 & -29.12 \\
Breast Muscles & -43.94 & -10.71 & 51.44 \\
Thigh & 26.67 & 61.70 & 1.63 \\
Drumstick & 29.26 & -18.38 & 67.00 \\
Gizzard fat & 85.6 & 59.00 & 2.20 \\
Abdominal fat & 1.7 & 8.2 & -16.40 \\
Skin & 4.86 & 0.69 & -7.36 \\
Neck & -2.19 & -6.54 & -1.27 \\
Wings & -6.98 & 4.71 & \\
\hline
\end{tabular}

*MS= the cross between Muscovy male with Sudani female

\section{REFERENCE}

Abdel-Samie, R. E., and J. D. Farrell, 1986. Carcass composition and carcass characteristics of ducks. Pages 83-101 in: Duck Production Science and World Practice (Farrell and Stapleton, Eds.).University of New England, Amidale, Australia.

Baeza, E., M. R. Salichon, G. March and H. Juin, 1998. Effect of sex on growth, technological and organoleptic characteristics of the Muscovy duck breast muscle. Brit Poult. Sci. 39: 389-403.

Bochno, R and A. Lewczuk, 1986. The content of edible and inedible parts of duck bodies depend on age. Proc. of the 7th Europ. Poult Conf. (published by WSPA French Branch. 12: 12701275).

Bokkers, E. A. M. and P. Koene, 2003. Behavior of fast and slow growing broilers to 12 weeks of age and the physical consequences. Applied Anim. Behavior Sc. 81:59-72. 
Farhat, A. G, 1999a. Growth and IGF-1 response to breast muscle selection by ultrasound and dietary protein programed in Pekin ducks. Ph.D. thesis. Anim, Sci, Dep, Mcgill Univ Canada.

Gorski, J, 1997 The effect of two-way crossbreeding of Pekin ducks of P-11, P-22, P-44 and P-55 strains on fleshing and fatness of crossbred ducks. Proceedings of 11th European Symposium on Waterfowl. September 8-10, Nantes, 354-360.

Gorski, J, 1997b. The effects of two-way crossbreeding of Pekin ducks of P-11, P-22, P-44 and $\mathrm{P}-55$ strains of fat and protein content in the muscles of crossbred ducks. Proceedings of 11th European Symposium on Waterfowl. September 8-10, Nantes, 362-367.

Gorski, J and I. Wzrost, 1990. Proporcje podrobów, produktów ubocznych i składników tkankowych tuszki u kaczek rasy pekin w okresie odchowu. Przegląd Naukowej Literatury Zootechnicznej, 35: 147-154.

Hellmeister, F. P., J. F. Menten, M. A da Silva., A. A. D. Coelho. V. J. M. Savino, 2003. Efeito de genótipo e do sistema de criacao sobre o desempenho de frangos tipo caipira. Revista Brasileira de Zootecnia, 32: 1883-1889.

Kim, H. K., E. C. Hong, B. S. Kang, M. N. Park, B. Y. Seo, H. J., Choo and S. H. Na, 2010. Effect of crossbreeding of Korean native duck and broiler ducks on performance and carcass yield, Korean J. Poult. Sci. 37 229-235.

Kwon, H. J., Y. K. Choo, Y. I. Choi, E. J. Kim, H. K. Kim, K. N. Heo, H. C. Choi, S. K. Lee, C. J. Kim, B. G. Kim, C. W. Kang, B. K. An, 2014. Carcass Characteristics and Meat Quality of Korean Native Ducks and Commercial Meat-type Ducks Raised under Same Feeding and Rearing Conditions. Asian-Australasian J. Anim. Sci. 27(11): 1638-1643.

Makram, A. 2015. Improving the productive performance of native duck breed by crossing with standard commercial duck breed. $\mathrm{PhD}$, thesis. Faculty of Agriculture, Ain Shams Univ, Egypt.

Makram, A., A. H. EL-Attar and A. Galal, 2015. The developed hybrids from the Egyptian Muscovy duck (Sudani duck). Book, lambert. ISBN, 978-3659-78415-6.
Makram. A, 2016. Ducks world (Review Article). The 9th International Poultry Conference from 710 November.463-486.

Makram. A., A. Galal and A. H. EL-Attar, 2016. Carcass Parameters Comparison between Two Crosses from Sudani Duck (Egyptian Muscovy) .The 9th International Poultry Conference from 710 November.233-243.

Marie-Etancelin, C., H. Chapuis, J. M. Brun, C. Larzul, M. M. Mailon-Richard and R. Rouvier, 2008. Genetic and selection of mule ducks in France: a review World poultry science, 64: 187207.

Pikul J., Doruchowski W., Tanski S. and Reksinski T, 1987. Slaughter yields, carcass composition, chemical analysis and technological properties of Muscovy and Pekin ducks. In Polish with English summary. Zeszyty Naukowe Drobiarstwa 4, 7392.

Pingel, H, 1997. Perspective of the production of waterfowl. In: 11th European Symp. On Waterfowl, Nantes, France, 128-134.

Pingel, H, 1999. Influence of breeding and management on the efficiency of duck production, lohman information No. 22, page

Ricard, F. H., H. de Carville and G. Marche, 1988. Etude comparative de la composition anatomique des canards de Barbarie, Pekin et Mulard. "La genetique de canard de Barbarie (Carina moschata) et du mulard". Toulouse-Auzeville (France Colloques de I'INRA, 42, 74-97).

SAS Institute, 2001. SAS/STAT User's Guide Version 8.2 ed: Statistics. SAS Institute Inc., Cary, NC.

Stanislaw, W, 1999: Current problems of waterfowl genetic and breeding. Proceeding 1st world waterfowl conference Taiwan.

Vernam, J. P, 1998. The relationships of wests in Pekin duck production. World Poultry i4 (1O): M35.

Wawro, K. K., E. Wilkiewicz- Wawro, K. K. Kleczek and W. Brzozowski, 2004. Slaughter value and meat quality of Muscovy and Pekin ducks and their crossbreds and evaluation of hetrosis Effects. Arch .Tierz.3: 287-299.

Zeidler, G, 1998. Poultry products in the $21 \mathrm{st}$ century. In: Proc. $10^{\text {th }}$ Europe Poultry Conf, 132141. 
صفات الأبيحة في سلالة البط السوداني والمسكوفي والهجين بينهم عامر مكرم علي، .أحمد جلال السيد، أحمد حاتم ابراهيم العطار قسم إنتاج الدواجن، كلية الزراعة، جامعة عين شعس، القاهرة، مصر

تستخدم الهجن في البط لتحسين صفات الذبيحة حيث نجد ان البط البكيني الأبيض و المسكوفي مختلفين في صفات الذبيحة. في هذه التجربة تم تلقيح ذكور البط المسكوفي مع إناث البط السوداني. و عند وصول البط الي عمر التسويق تم استخدام 17 طائر (1 ذكور +ᄉ إناث) من كل سلالة بالاضافة الي الهجين الناتج بينهم ويسمي MS وذللك لتقدير صفات الذبيحة.أشارت النتائج الي عدم وجود فروق معنوية بين السلالات و الهجين لنسبة الذبيحة المجوفة بينما كانت الذكور أعلي معنويا من الاناث لنسبة الذبيحة المجوفه. كان الهجين (MS) أعلي لصفئه الحوائج (الكبد+القونصة+القلب) مقارنة بالبط المسكوفي بينما كانت سلالة البط السوداني وسط بينهم. لم يكن هناك اختلافات معنوية بين

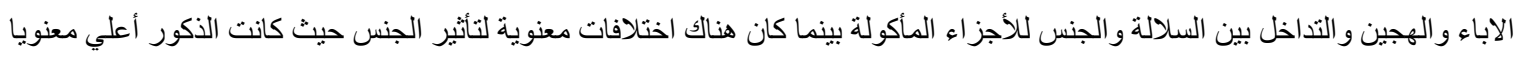
لنسبة الاجز اء المأكولة مقارنة بالاناث. وبالنسبة لعضة الــthigh كان هجين الـMS أعلي معنويا مقارنة بالبط السوداني يليه البط المسكوفي وكانت الذكور أعلي معنويا من الاناث لعضلة الــthigh . في النهاية نجد ان قوة الهجين كانت سالبة في صفات الاجزاء المأكولة وعضلة الصدر الكبري والصغري واجمالي عضلات الصدر ونسبة الجلد والرقبة والجناح بينما سجل الهجين قيم موجبة للحوائج (الكبد+القونصة+القلب) و عضلة الــthigh و عضلة الـ drumstick ودهن القونصة ودهن البطن. 